\title{
PENGARUH KUALITAS PELAYANAN TERHADAP NIAT ULANG DENGAN MENGGUNAKAN PRODUK YANG LAIN MELALUI KEPERCAYAAN NASABAH BANK SYARIAH MANDIRI KANTOR CABANG

\author{
BOULEVARD DI SURABAYA
}

\author{
Aditya Okta Viandhy \\ Mahasiswa Program Studi S1 Ekonomi Islam - Fakultas Ekonomi dan Bisnis - Universitas \\ Airlangga \\ Email : Adityaoktaviandhy@yahoo.co.id \\ Ririn Tri Ratnasari \\ Departemen Ekonomi Syariah - Fakultas Ekonomi dan Bisnis - Universitas Airlangga \\ Email : Ri.ratnasari@gmail.com
}

\begin{abstract}
:
This study aims to determine the effect of service quality on intention to re-use products other Bank Syariah Mandiri through the trust as an intervening variable.

The method used is quantitative approach. Characteristics of the sample used is 30 customers of Bank Syariah Mandiri Boulevard branch in Surabaya who use a particular product. Sampling is using nonprobability sampling with purposive sampling procedure. The analytic technique is used path analysis or path analysis.

The results showed that the quality of services significantly influence customer confidence in Bank Syariah Mandiri Boulevard in Surabaya. Other results show that trust significantly influence purchase intention by re-using the products of Bank Syariah Mandiri others. While service quality does not significantly influence customers' purchase intention by re-using the products of Bank Syariah Mandiri others.

Advice for Bank Syariah Mandiri branch in Surabaya Boulevard to always improve the quality of service to customers through good SERVQUAL and maintain the trust that exists between the customer and the bank to always be honest and maintain the trust that has been given by the customer to the bank. For further research can add variable customer loyalty in the Islamic perspective.
\end{abstract}

Keywords: Service Quality, Beliefs, Repurchase Intention

\section{PENDAHULUAN}

Lembaga kevangan seperti perbankan merupakan instrumen penting dalam memperlancar jalannya pembangunan suatu bangsa. Di Indonesia sendiri telah banyak muncul perbankan syariah. Saat ini perbankan syariah telah memasuki persaingan global, merupakan suatu tantangan yang harus dihadapi dan ditangani oleh bank syariah untuk dapat memberikan kontribusi dalam pembangunan bangsa melalui pemberdayaan ekonomi umat.
Banyaknya bank syariah yang berdiri, nasabah akan dihadapkan pada banyak pilihan akan produk bank syariah yang ditawarkan. Bagi nasabah, pelayanan yang bermutu sangat penting. Oleh karena itu persaingan akan sangat dipengaruhi oleh kemampuan bank dalam memberikan pelayanan terbaik dibandingkan pesaingnya (Karim, 2004:25).

Kualitas pelayanan memberikan suatu dorongan kepada nasabah untuk menjalin ikatan yang kuat dengan bank 
syariah. Ikatan seperti ini dalam jangka panjang memungkinkan bank syariah untuk memahami dengan seksama harapan pelanggan serta kebutuhan mereka (Hermansyah, 2008). Kualitas pelayanan menjadi salah satu faktor penting yang harus diperhatikan oleh setiap bank syariah untuk mendapatkan kepercayaan dari nasabah. Jika pelayanan yang diberikan oleh bank syariah kepada para nasabahnya dirasa kurang memuaskan, nasabah biasanya akan mengurungkan niatnya untuk memilih bank tersebut (Othman and Owen, 2001).

Di samping kualitas pelayanan sebenarnya bank syariah dapat meningkatkan kepercayaan nasabah karena kepercayaan mempengaruhi secara positif penilaian nasabah secara keseluruhan (Sirdesmukh dkk, 2002). Kepercayaan didefiniskan oleh Moorman, Deshpande dan Zaltman (1993 : 82) sebagai keinginan untuk menggantungkan diri pada mitra bertukar yang dipercayai. Kepercayaan juga menjadi salah satu faktor kunci fokus dalam pengembangan hubungan antar nasabah. Kepercayaan sering dianggap sangat penting juga untuk hubungan jangka panjang dan sangat menentukan dalam mempengaruhi niat nasabah dalam memilih produk bank yang akan digunakan.

Di samping kualitas pelayanan dan kepercayaan, niat juga menjadi faktor yang dipertimbangkan dalam penelitian ini. Niat adalah kecenderungan seseorang untuk memilih melakukan atau tidak melakukan sesuatu pekerjaan. Niat diasumsikan sebagai faktor pemotivasi yang ada di dalam diri individu yang mempengaruhi perilaku. Niat ini tercermin dari seberapa besar keinginan untuk mencoba dan seberapa kuat usaha yang dialokasikan untuk mewujudkan perilaku tertentu (Ajzen, 1991:181). Disini niat yang dimaksudkan adalah niat ketika nasabah sudah mendapatkan kualitas pelayanan yang baik dan juga kepercayaan yang terbangun baik antara bank syariah dengan nasabah, apakah nasabah masih berniat untuk menggunakan produk bank syariah yang lainn selain dari produk yang biasanya digunakan. Jadi bisa terlihat juga seberapa besar pengaruh faktor kualitas pelayanan dan kepercayaan terhadap niat nasabah dalam memilih produk.

Di dalam penelitian ini yang akan dijadikan obyek penelitian adalah Bank Syariah Mandiri di Surabaya, karena bank tersebut dalam segi keuangan, misalnya pendapatan, laba, pembiayaan dan lainnya paling besar dibandingkan bank syariah yang lain. Selain itu, bank ini banyak melakukan aktivitas fungsi sosial yang dimasukkan dalam aktifitas pemasaran serta memiliki nasabah yang cukup banyak, selain itu Bank Syariah Mandiri adalah bank yang memiliki nasabah paling loyal dan mendapat peringkat pertama dalam Indonesian Bank Loyalty Index (IBLI) tahun 2011 yang diselenggarakan oleh Mark Plus Insight bekerja sama dengan Majalah Infobank 
untuk indeks loyalitas nasabah (customer loyalty index) tabungan syariah. Suatu bentuk loyalitas yang dimaksud contohnya adalah mau menggunakan ulang produk bank tersebut. (www.infobanknews.com)

Hal inilah yang mendasari penulis untuk melakukan penelitian ini yang berjudul "Pengaruh Kualitas Pelayanan Terhadap Niat Ulang Menggunakan Produk Lain Melalui Kepercayaan Nasabah Bank Syariah Mandiri Kantor Cabang Boulevard di Surabaya".

\section{A. Rumusan Masalah}

Berdasarkan latar belakang di atas, maka rumusan masalah dalam penelitian ini adalah:

1. Apakah kualitas pelayanan berpengaruh terhadap kepercayaan nasabah Bank Syariah Mandiri?

2. Apakah kualitas pelayanan berpengaruh terhadap niat ulang nasabah Bank Syariah Mandiri dengan menggunakan produk yang lain?

3. Apakah kepercayaan berpengaruh terhadap niat ulang nasabah Bank Syariah Mandiri dengan menggunakan produk yang lain?

\section{Landasan Teori}

\section{A. Kualitas Pelayanan}

Gagliano dalam Dwi Haryono Wiratno (1998), mengatakan bahwa kualitas pelayanan (Service Quality) adalah pandangan konsumen terhadap hasil perbandingan antara ekspektasi konsumen dengan kenyataan yang diperoleh dari pelayanan. Sedangkan menurut Crownin dan taylor (1992), kualitas jasa/pelayanan adalah kinerja dari jasa/pelayanan yang diterima oleh konsumen itu sendiri dan konsumen hanya akan dapat menilai kualitas dari pelayanan yang benar-benar mereka rasakan. Menurut Wyckof (dalam Simamora, 2003:180) kualitas pelayanan dapat didefinisikan sebagai tingkat keunggulan yang diharapkan dan pengendalian atas tingkat keunggulan tersebut untuk memenuhi keinginan konsumen.

Menurut Othman dan Owen (2011), Pengukuran kualitas pelayanan antara lain sebagai berikut:

1. Kepatuhan terhadap syariah (Sharia Compliance), meliputi kemampuan untuk mengikuti hukum syariah Islam

2. Bukti langsung (tangibility), meliputi fasilitas fisik perusahaan, perlengkapan, pegawai dan sarana komunikasi.

3. Empati (empathy), meliputi kemudahan dalam melakukan hubungan

4. Kehandalan (reliability), yaitu kemampuan perusahaan dalam memberikan pelayanan yang dijanjikan dengan segera, akurat dan memuaskan kepada konsumen.

5. Daya tanggap (responsiveness), yaitu inisiatif para personil perusahaan untuk membantu konsumen dan memberikan pelayanan dengan memuaskan.

6. Jaminan (assurance), meliputi pengetahuan, kemampuan, kesopanan dari personil perusahaan 
dan sifat dapat dipercaya, bebas dari bahaya, resiko dan keragu-raguan.

\section{B. Kepercayaan}

Kepercayaan (trust atau belief) merupakan keyakinan bahwa tindakan orang lain atau suatu kelompok konsisten dengan kepercayaan mereka. Kepercayaan lahir dari suatu proses secara perlahan kemudian terakumulasi menjadi suatu bentuk kepercayaan (Pradiansyah, 1999). Kepercayaan konsumen dapat dijelaskan melalui 3 dimensi yaitu pengalaman masa lalu, informasi dan antusiasme. Kepercayaan konsumen tergantung dari pengalaman konsumen dalam mengkonsumsi barang atau jasa dan menerima informasi yang baik dari penyedia jasa (Dabholkar, 1995). Secara konseptual, kepercayaan (trust) ada jika suatu pihak punya keyakinan (confidence) terhadap integritas dan reliabilitas pihak lain (Morgan dan Hunt, 1994:23), sedangkan Deshpande dan Zaltman (1993:82), dalam Morgan dan Hunt (1994:23) menyatakan kepercayaan sebagai kemauan untuk mempunyai pihak lain yang telah diyakini. Kedua definisi menekankan akan pentingnya kepercayaan. Dunn et al, (2008) mengungkapkan bahwa mekanisme kepercayaan merupakan komponen penting dan efektif dalam keputusan pembelian seorang pelanggan, walaupun pelanggan tersebut tidak terlalu akrab dengan suatu produk yang ditawarkan.

Menurut Morgan dan Hunt (1994) terdapat enam indikator kepercayaan, antara lain:
1. Pemberian pelayanan yang konsisten

2. Penawaran produk-produk yang berkualitas

3. Terbuka dalam penyampaian informasi tentang produk-produk yang ditawarkan

4. Ketepatan waktu dalam pelayanan produk

5. Pemberian respon yang baik

6. Pemberian kesan yang baik

\section{Niat Beli Ulang (Repurchase Intention)}

Schiffman dan Kanuk (2004:173) menjelaskan bahwa niat beli ulang adalah rencana konsumen yang mendorong kesediaannya untuk melakukan pembelian kembali atas produk yang telah dibelinya.

Menurut Ferdinand (2002:25-26) niat beli ulang dapat diukur melalui indikator-indikator sebagai berikut:

1. Niat transaksional, yaitu kecenderungan seseorang untuk membeli kembali produk yang telah dikonsumsinya dan produk lain dari penyedia jasa yang sama.

2. Niat preferensial, yaitu niat yang menggambarkan perilaku seseorang yang cenderung memiliki pilihan utama pada produk yang telah dikonsumsi. Preferensi ini hanya dapat diganti bila terjadi sesuatu dengan produk preferensinya.

3. Niat referensial, yaitu kecenderungan seseorang untuk mereferensikan produk yang sudah dibelinya, agar juga dibeli oleh orang lain, dengan referensi pengalaman konsumsinya. 
4. Niat eksploratif, yaitu niat yang menggambarkan perilaku seseorang yang selalu mencari informasi mengenai produk yang diminati serta mencari informasi yang mendukung sifat-sifat positif dari produk langganan.

\section{Hipotesis Penelitian}

$\mathrm{H}_{1}$ : Kualitas pelayanan berpengaruh terhadap kepercayaan nasabah Bank

Syariah Mandiri.

$\mathrm{H}_{2}$ : Kualitas pelayanan berpengaruh terhadap niat ulang nasabah Bank Syariah Mandiri dengan menggunakan produk yang lain.

$\mathrm{H}_{3}$ : Kepercayaan berpengaruh terhadap niat ulang nasabah Bank Syariah Mandiri dengan menggunakan produk yang lain.

\section{Model Analisis}

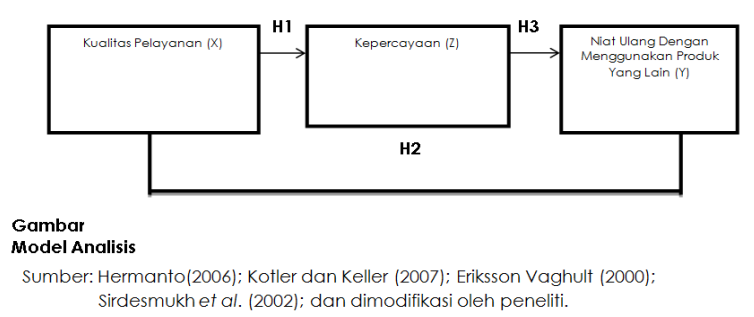

\section{METODE PENELITIAN}

Berdasarkan variabel-variabel yang telah diteliti dan model penelitian yang telah disusun, maka penelitian ini menggunakan pendekatan kuantitatif untuk menjawab rumusan masalah. Pendekatan kuantitatif menitikberatkan pada pengujian hipotesis, mengukur variabel yang sedang diteliti dan akan menghasilkan kesimpulan yang dapat digeneralisasi. Menurut Anshori dan Iswati (2009:13) penelitian kuantitatif merupakan penelitian yang terstruktur dan mengkuantifikasikan data untuk dapat digeneralisasikan.

\section{Definisi Operasional}

\section{Kualitas Pelayanan ( $x$ )}

Menurut Kotler (2001:310) kualitas adalah "seluruh ciri serta sifat suatu produk atau layanan yang berpengaruh pada kemampuan untuk memuaskan kebutuhan yang dinyatakan atau yang tersirat". Sedangkan Kotler dan Amstrong (2001:347) mendefinisikan jasa sebagai tindakan atau manfaat yang ditawarkan oleh suatu perusahaan kepada pihak lain yang tidak berwujud dan tidak menghasilkan kepemilikan sesuatu, baik dalam produk fisik atau tidak. Menurut Crownin dan taylor (1992), kualitas jasa/pelayanan adalah kinerja dari jasa/pelayanan yang diterima oleh konsumen itu sendiri dan konsumen hanya akan dapat menilai kualitas dari pelayanan yang benar-benar mereka rasakan. Definisi operasional kualitas layanan dalam penelitian ini adalah kinerja Bank Syariah Mandiri dalam memberikan jasa/pelayanan kepada nasabah.

Indikator yang digunakan antara lain:

1. Tidak adanya bunga yang diberikan oleh Bank Syariah Mandiri

2. Bank Syariah Mandiri menyediakan produk dan jasa syariah

3. Bank Syariah Mandiri memberikan bagi hasil 
4. Bank Syariah Mandiri selalu memakai aqad syar'i dalam setiap transaksi

5. Ruang tunggu Bank Syariah Mandiri selalu dalam keadaan bersih

6. Karyawan Bank Syariah Mandiri berpenampilan rapi

7. Bank Syariah Mandiri memberikan pelayanan sesuai janjinya

8. Call center Bank Syariah Mandiri dapat dihubungi dengan mudah

9. Karyawan Bank Syariah Mandiri bersedia dengan senang hati melayani nasabah

10. Karyawan Bank Syariah Mandiri melayani transaksi dengan cepat / segera

11. Bank Syariah Mandiri menjamin keamanan nasabah dalam bertransaksi

12. Karyawan Bank Syariah Mandiri bersikap ramah dan sopan dalam melayani nasabah

13. Karyawan Bank Syariah Mandiri memberikan informasi mengenai produk dengan jelas

14. Karyawan Bank Syariah Mandiri memiliki kepekaan dalam menerima keluhan dan pengaduan nasabah

15. Karyawan Bank Syariah Mandiri memberikan pelayanan yang adil ke setiap nasabah

Indikator kualitas pelayanan akan diukur dengan menggunakan skala Likert dengan empat tingkatan, dengan menghilangkan jawaban tengah (netral) dengan alasan (Azwar, 1997):

a. Memiliki penafsiran ganda b. Jawaban netral tidak memberikan ketegasan pendapat responden ke arah setuju atau tidak setuju

c. Responden memiliki kecenderungan memilih jawaban netral.

Skor 1 untuk tingkatan terendah, dan skor 4 untuk tingkatan tertinggi. Skala Likert tersebut adalah sebagai berikut:

a. Sangat tidak setuju $=1$

b. Tidak setuju $=2$

C. Setuju $=3$

d. Sangat setuju $\quad=4$

\section{Kepercayaan (Z)}

Kepercayaan adalah memiliki keyakinan kepada pihak lain (mitra pertukarannya) dalam sebuah hubungan dikarenakan mempunyai kehandalan dan integritas yang tinggi (Morgan dan Hunt, 1994:23). Oleh karena itu, definisi operasional kepercayaan dalam penelitian ini adalah sikap percaya dan yakin yang dimiliki oleh nasabah terhadap Bank Syariah Mandiri yang memiliki integritas dalam memberikan pelayanan terbaiknya untuk melayani nasabah. Variabel ini dikembangkan berdasarkan penelitian Morgan dan Hunt (1994) sehingga dapat diukur dan disesuaikan dengan fakta di lapangan dengan 6 pertanyaan sebagai berikut:

1. Nasabah percaya Bank Syariah Mandiri memberikan pelayanan produk syariah secara Istiqomah (konsisten).

2. Nasabah percaya Bank Syariah Mandiri menawarkan produk-produk 
yang memberikan manfaat lebih kepada nasabah.

3. Nasabah percaya Bank Syariah Mandiri memiliki kredibilitas tinggi dalam memberikan pelayanan perbankan syariah

4. Nasabah percaya Bank Syariah Mandiri melayani nasabah secara efisien.

5. Nasabah percaya Bank Syariah Mandiri mampu memberikan respon yang baik terhadap nasabahnya.

6. Nasabah percaya Bank Syariah Mandiri mampu memberikan kesan yang baik terhadap nasabahnya.

Indikator di atas akan diukur dengan menggunakan skala Likert dengan empat tingkatan, dengan menghilangkan jawaban tengah (netral) (Azwar, 1997).

\section{Niat Ulang Dengan Menggunakan Produk Yang Lain $(Y)$}

Menurut Schiffman dan Kanuk (2004:173) niat beli ulang adalah bentuk respon positif yang menunjukkan rencana konsumen untuk melakukan pembelian kembali atas produk yang pernah dibelinya. Dengan demikian, definisi operasional niat beli ulang dalam penelitian ini adalah niat ulang nasabah dengan menggunakan produk Bank Syariah Mandiri yang lain. Niat beli ulang dalam penelitian ini diukur dengan beberapa indikator yang diambil dari beberapa teori (Chamburi:2009; Ling et al:2010; Hellier et al:2003; dan Tasmara, 2001:232) dan disesuaikan dengan penelitian di lapangan, yaitu:
1. Nasabah berencana akan menggunakan ulang produk Bank Syariah Mandiri yang lain.

2. Nasabah akan menjadikan Bank Syariah Mandiri sebagai pilihan utama dalam pemilihan produk bank.

Indikator di atas akan diukur dengan menggunakan skala Likert dengan empat tingkatan, dengan menghilangkan jawaban tengah (netral) (Azwar, 1997).

\section{Prosedur Pengumpulan Data}

Untuk mengetahui sampel penelitian maka harus mengerti pula besaran dari populasi yang digunakan dalam penelitian. Populasi merupakan sekelompok orang, kejadian atau segala sesuatu yang mempunyai karakteristik tertentu (Indriantoro dan Supomo, 2002: 115-116). Menurut Nazir (2003:271), populasi merupakan kumpulan dari individu dengan kualitas serta ciri-ciri yang ditetapkan. Sedangkan sampel adalah bagian atau wakil populasi yang memiliki ciri-ciri dapat mencerminkan populasi. Populasi dalam penelitian ini adalah seluruh nasabah Bank Syariah Mandiri Kantor Cabang Boulevard Surabaya.

Metode penarikan sampel adalah nonprobability sampling dengan prosedur purposive sampling. Dengan nonprobability sampling, anggota populasi tidak memiliki peluang terpilih yang sama untuk dijadikan sampel. Dan pada prosedur purposive sampling, pengambilan sampel dilakukan berdasar pertimbangan tertentu (Sugiono, 2008:85). Adapun karakteristik sampel yang 
digunakan dalam penelitian ini adalah nasabah Bank Syariah Mandiri cabang Bolevard Surabaya yang menggunakan produk tertentu. Misalkan nasabah produk tabungan apakah nantinya bersedia menjadi nasabah produk pembiayaan. Begitu juga sebaliknya atau mungkin yang lain. Pada penelitian ini, Menurut Wibisono, ukuran sampel yang atau responden dapat ditentukan paling sedikit 5-10 kali jumlah variabel. Karena dalam penelitian ini terdapat 3 variabel, maka jumlah sampel yang ditetapkan adalah $10 \times 3=$ 30 sampel. Dengan demikian, jumlah responden dalam penelitian ini ditetapkan sebesar 30 nasabah Bank Syariah Mandiri cabang Boulevard Surabaya.

Untuk pengumpulan data yang dibutuhkan dalam penelitian ini, dilakukan beberapa teknik, yaitu:

\section{Studi Dokumentasi}

Mengumpulkan data dan informasi melalui buku, literatur, serta penelitian sebelumnya, arsip atau dokumen perusahaan yang berkaitan dengan permasalahan yang diangkat, gambaran umum perusahaan dan struktur organisasi perusahaan.

\section{Survei Lapangan}

Kuesioner yaitu metode pengumpulan data dengan cara mengajukan daftar pertanyaan yang berisi pilihan skor tertentu.

\section{Teknik Analisis Data}

\section{Analisis Statistik Deskriptif}

Analisis statistik deskriptif digunakan dalam penelitian ini untuk memberikan gambaran atau deskripsi mengenai variabel-variabel penelitian yaitu kualitas pelayanan, niat ulang dengan menggunakan produk yang lain dan kepercayaan.

\section{Uji Kualitas Data}

Uji kualitas data dimaksudkan untuk mengetahui seberapa besar tingkat konsistensi dan akurasi data yang dikumpulkan dari penggunaan instrumen penelitian. Pengujian terhadap kualitas data penelitian ini dapat dilakukan dengan uji validitas dan uji reliabilitas.

\section{Uji Validitas}

Validitas adalah sejaun mana ketepatan dan kecermatan suatu alat ukur dalam melakukan fungsi pengukurannya (Azwar, 2001: 44). Dengan demikian, sebuah instrumen pengukuran dapat dikatankan valid jika instrumen tersebut memberikan hasil ukur yang sesuai dengan maksud dilakukannya pengukuran tersebut. Alat ukur dengan validitas tinggi berarti mempunyai varian kesalahan yang kecil, sehingga memberikan keyakinan bahwa data yang terkumpul merupakan data yang dapat dipercaya.

Uji validitas pada penelitian ini dilakukan dengan mengkorelasikan masing-masing pertanyaan dengan jumlah sekor untuk masing-masing variabel. Validitas data akan diukur dengan construct validity dengan teknik korelasi Pearson Product Moment (r). 
Korelasi Pearson Product moment digunakan bila ditujukan untuk menentukan keterkaitan antara ko-variasi pada dua variabel yang datanya berbentuk interval. Korelasi ProductMoment berada dalam rentang $r=-1,00$ sampai $r=+1,00$ sebagai batas. Kriterianya adalah apabila probabilitas (p) dari $r$ hitung kurang dari $a=0.05$, maka pernyataan dianggap tidak valid (Indriantoro dan Supomo, 1999:59). Uji validitas juga bisa dilakukan dengan membandingkan angka korelasi yang diperoleh secara statistik dengan angka kritik tabel korelasi nilai $r$. Bila $r$ hitung $>r$ tabel berarti data tersebut signifikan (valid) dan layak digunakan dalam pengujian hipotesis penelitian. Sebaliknya bila $r$ hitung $<r$ tabel berarti data tersebut tidak valid dan tidak akan diikutsertakan dalam pengujian hipotesis penelitian (Santoso, 2003:64 dalam Sari, 2012).

\section{Uji Reliabilitas}

Uji reliabilitas digunakan untuk mengetahui sampai sejauh mana suatu hasil pengukuran relatif konsisten apabila pengukuran dilakukan dua kali atau lebih. Dengan kata lain, reliabilitas menunjukkan konsistensi suatu alat ukur dalam mengukur gejala yang sama. Untuk mengetahui reliabilitas kuesioner,

penelitian ini menggunakan pendekatan pengukuran reliabilitas konsistensi internal dengan menghitung koefisien alpha. Koefisien alpha ini berkisar antara 0 sampai 1.
Dasar pengambilan keputusan, menurut Solimun (2005:14):

1. Jika alpha $\geq 0,6$, maka butir atau variabel tersebut reliabel.

2. Jika alpha $<0,6$, maka butir atau variabel tersebut tidak reliabel.

\section{Path Analysis (Analisis Jalur)}

Teknik analisis yang digunakan untuk menjawab permasalahan dan membuktikan hipotesis dalam penelitian ini adalah teknik analisis jalur. Analisis jalur mempunyai kedekatan dengan regresi berganda, atau dengan kata lain, regresi berganda merupakan bentuk khusus dari analisis jalur. Analisis jalur adalah suatu teknik untuk menganalisis hubungan sebab akibat yang terjadi pada regresi berganda jika variabel eksogennya mempengaruhi variabel endogen tidak hanya secara langsung tetapi juga secara tidak langsung (Rutherford, 1993 dalam Sarwono, 2006). Berdasarkan pernyataan diatas oleh Sarwono, pada saat melakukan path analysis hendaknya diperhatikan beberapa asumsi berikut ini:

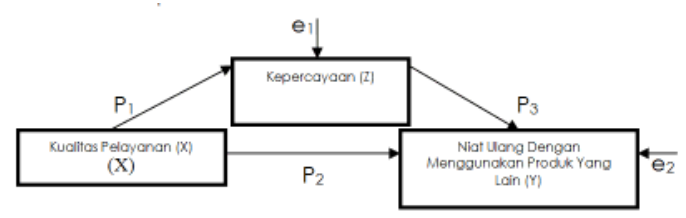

Keterangan:

$X=$ Variabel Eksogen

$Y=$ Variabel Endogen

$\mathrm{Z}=$ Variabel Intervening

1. Hubungan antara variabel dalam model haruslah linear dari variabel lainnya yang bersifat kausal

2. Variabel yang diamati bersifat aditif artinya variabel mempunyai sifat 
multiplikatif dan eksponensial tidak dapat digunakan

3. Semua variabel residu tidak mempunyai korelasi satu sama lain

4. variabel yang diukur berskala interval atau rasio.

Berdasarkan model di halaman sebelumnya, ditunjukkan bahwa kualitas pelayanan mempunyai hubungan langsung dengan niat ulang nasabah Bank Syariah Mandiri dalam menggunakan produk yang lain $\left(\mathrm{P}_{2}\right)$. Namun demikian, kualitas pelayanan juga mempunyai hubungan tidak langsung dengan niat ulang nasabah dengan menggunakan produk yang lain melalui kepercayaan $\left(\mathrm{P}_{1}\right)$ baru kemudian ke niat nasabah Bank Syariah Mandiri $\left(P_{3}\right)$. Anak panah $e_{1}$ menjelaskan jumlah varian variabel kepercayaan yang tidak dapat dijelaskan oleh variabel kualitas pelayanan dalam penelitian ini. Sedangkan anak panah $e_{2}$, menjelaskan varian variabel niat ulang nasabah dengan menggunakan produk lainnya yang tidak dapat dijelaskan oleh variabel kualitas pelayanan dan kepercayaan.

Untuk mengetahui pengaruh langsung dan pengaruh tidak langsung dapat diestimasi dan koefisien beta (Path). Persamaan analisis jalur adalah sebagai berikut:

$Z=P_{1} X+\varepsilon 1$

$Y=P_{2} X+\varepsilon 2$

$Y=P_{3} X+\varepsilon_{3}$

Keterangan
$Y=$ Niat ulang dengan menggunakan produk yang lain

$X=$ Kualitas Pelayanan

$Z$ = Kepercayaan

$\mathrm{P}_{1}, \mathrm{P}_{2}$, dan $\mathrm{P}_{3}=$ standardized coefficient

$\varepsilon_{1}, \varepsilon_{2}$, dan $\varepsilon_{3}=$ Pengaruh dari variabel lain di luar variabel yang diteliti

\section{HASIL DAN PEMBAHASAN}

\section{A. Validitas dan Reliabilitas}

Hasil Uji Validitas Variabel Kualitas Pelayanan

\begin{tabular}{|c|c|c|}
\hline Item & r hitung & Keterangan \\
\hline $\begin{array}{lr}\text { Tidak } & \text { adanya } \\
\text { bunga } & \text { yang } \\
\text { diberikan } & \text { oleh } \\
\text { Bank } & \text { Syariah } \\
\text { Mandiri } & \\
\end{array}$ & 0,575 & Valid \\
\hline $\begin{array}{l}\text { Bank Syariah } \\
\text { Mandiri } \\
\text { menyediakan } \\
\text { produk dan jasa } \\
\text { syariah } \\
\end{array}$ & 0,476 & Valid \\
\hline $\begin{array}{l}\text { Bank Syariah } \\
\text { Mandiri } \\
\text { memberikan } \\
\text { bagi hasil }\end{array}$ & 0,768 & Valid \\
\hline $\begin{array}{lr}\text { Bank } & \text { Syariah } \\
\text { Mandiri } & \text { selalu } \\
\text { memakai } & \text { aqad } \\
\text { syar'i } & \text { dalam } \\
\text { setiap transaksi }\end{array}$ & 0,728 & Valid \\
\hline $\begin{array}{lr}\text { Ruang tunggu } \\
\text { Bank Syariah } \\
\text { Mandiri selalu } \\
\text { dalam keadaan } \\
\text { bersih } \\
\end{array}$ & 0,316 & Valid \\
\hline $\begin{array}{l}\text { Karyawan Bank } \\
\text { Syariah Mandiri } \\
\text { berpenampilan } \\
\text { menarik }\end{array}$ & 0,708 & Valid \\
\hline $\begin{array}{l}\text { Bank Syariah } \\
\text { Mandiri } \\
\text { memberikan } \\
\text { pelayanan } \\
\text { sesuai janjinya }\end{array}$ & 0,799 & Valid \\
\hline
\end{tabular}


JESTT Vol. 1 No. 8 Agustus 2014

\begin{tabular}{|c|c|c|}
\hline $\begin{array}{l}\text { Call center Bank } \\
\text { Syariah Mandiri } \\
\text { dapat } \\
\text { dihubungi } \\
\text { dengan mudah }\end{array}$ & 0,844 & Valid \\
\hline $\begin{array}{l}\text { Karyawan Bank } \\
\text { Syariah Mandiri } \\
\text { bersedia } \\
\text { dengan senang } \\
\text { hati melayani } \\
\text { nasabah }\end{array}$ & 0,792 & Valid \\
\hline $\begin{array}{l}\text { Karyawan Bank } \\
\text { Syariah Mandiri } \\
\text { melayani } \\
\text { transaksi } \\
\text { dengan cepat }\end{array}$ & 0,697 & Valid \\
\hline $\begin{array}{l}\text { Bank Syariah } \\
\text { Mandiri } \\
\text { menjamin } \\
\text { keamanan } \\
\text { nasabah dalam } \\
\text { bertransaksi }\end{array}$ & 0,599 & Valid \\
\hline $\begin{array}{l}\text { Karyawan Bank } \\
\text { Syariah Mandiri } \\
\text { bersikap ramah } \\
\text { dan sopan } \\
\text { dalam melayani } \\
\text { nasabah }\end{array}$ & 0,689 & Valid \\
\hline $\begin{array}{l}\text { Karyawan Bank } \\
\text { Syariah Mandiri } \\
\text { memberikan } \\
\text { informasi } \\
\text { mengenai } \\
\text { produk dengan } \\
\text { jelas }\end{array}$ & 0,750 & Valid \\
\hline $\begin{array}{l}\text { Karyawan Bank } \\
\text { Syariah Mandiri } \\
\text { memiliki } \\
\text { kepekaan } \\
\text { dalam } \\
\text { menerima } \\
\text { keluhan dan } \\
\text { pengaduan } \\
\text { nasabah }\end{array}$ & 0,575 & Valid \\
\hline $\begin{array}{l}\text { Karyawan Bank } \\
\text { Syariah Mandiri } \\
\text { memberikan } \\
\text { pelayanan yang } \\
\text { adil ke setiap } \\
\text { nasabah }\end{array}$ & 0,476 & Valid \\
\hline
\end{tabular}

Sumber: hasil olah data

Hasil diatas menunjukkan bahwa seluruh indikator untuk variabel kualitas pelayanan adalah lebih besar dari 0,3 sehingga seluruh indikator dinyatakan valid atau dapat mengukur variabel kualitas pelayanan.

Hasil Uji Validitas Variabel Kepercayaan

\begin{tabular}{|c|c|c|}
\hline Item & $\begin{array}{l}r \\
\text { hitung }\end{array}$ & Keterangan \\
\hline $\begin{array}{l}\text { Nasabah yakin } \\
\text { Bank Syariah } \\
\text { Mandiri dapat } \\
\text { memberikan } \\
\text { pelayanan yang } \\
\text { konsisten }\end{array}$ & 0,409 & Valid \\
\hline $\begin{array}{l}\text { Nasabah yakin } \\
\text { Bank Syariah } \\
\text { Mandiri } \\
\text { menawarkan } \\
\text { produk-produk } \\
\text { perbankan yang } \\
\text { berkualitas }\end{array}$ & 0,480 & Valid \\
\hline $\begin{array}{l}\text { Nasabah yakin } \\
\text { Bank Syariah } \\
\text { Mandiri terbuka } \\
\text { ketika } \\
\text { memberikan dan } \\
\text { menyampaikan } \\
\text { informasi tentang } \\
\text { produk-produk } \\
\text { yang } \\
\text { ditawarkannya } \\
\text { kepada nasabah }\end{array}$ & 0,465 & Valid \\
\hline $\begin{array}{lr}\text { Nasabah } & \text { yakin } \\
\text { bahwa } & \text { Bank } \\
\text { Syariah } & \text { Mandiri } \\
\text { selalu tepat } \\
\text { waktu dalam hal } \\
\text { pelayanan } \\
\text { produk kepada } \\
\text { nasabah }\end{array}$ & 0,703 & Valid \\
\hline $\begin{array}{l}\text { Nasabah merasa } \\
\text { Bank Syariah } \\
\text { Mandiri selalu } \\
\text { memberikan } \\
\text { respon yang baik } \\
\text { terhadap } \\
\text { nasabahnya }\end{array}$ & 0,732 & Valid \\
\hline $\begin{array}{l}\text { Nasabah merasa } \\
\text { Bank Syariah } \\
\text { Mandiri selalu } \\
\text { memberikan } \\
\text { kesan yang baik } \\
\text { terhadap } \\
\text { nasabahnya }\end{array}$ & 0,740 & Valid \\
\hline
\end{tabular}


Sumber: hasil olah data

Hasil di halaman sebelumnya menunjukkan bahwa seluruh indikator untuk variabel kepercayaan adalah lebih besar dari 0,3 sehingga seluruh indikator dinyatakan valid atau dapat mengukur variabel kepercayaan.

Hasil Uji Validitas Variabel Niat Ulang Dengan Menggunakan Produk Yang Lain

\begin{tabular}{|c|c|c|}
\hline Item & $\begin{array}{l}r \\
\text { hitung }\end{array}$ & Keterangan \\
\hline $\begin{array}{l}\text { Nasabah } \\
\text { berencana akan } \\
\text { menggunakan } \\
\text { Ulang produk Bank } \\
\text { Syariah Mandiri } \\
\text { yang lain. }\end{array}$ & 0,631 & Valid \\
\hline $\begin{array}{lr}\text { Nasabah } & \text { akan } \\
\text { menjadikan } & \text { Bank } \\
\text { Syariah } & \text { Mandiri } \\
\text { sebagai } & \text { pilihan } \\
\text { Utama } & \text { dalam } \\
\text { pemilihan } & \text { produk } \\
\text { bank. } & \\
\end{array}$ & 0,631 & Valid \\
\hline
\end{tabular}

Sumber: hasil olah data

\section{B. Uji Reliabilitas}

Hasil Uji Reliabilitas

\begin{tabular}{|l|c|l|}
\hline \hline Variabel & Alpha & Reliabilitas \\
\hline $\begin{array}{l}\text { Kualitas } \\
\text { pelayanan }\end{array}$ & 0.925 & Reliabel \\
\hline Kepercayaan & 0.817 & Reliabel \\
\hline $\begin{array}{l}\text { Niat } \\
\text { menggunakan } \\
\text { produk lain }\end{array}$ & 0.772 & Reliabel \\
\hline \hline
\end{tabular}

Sumber: hasil olah data

Nilai reliabilitas konsistensi internal ditunjukkan dalam tabel diatas, untuk koefisien alfa dinyatakan reliabel karena lebih besar dari 0,6. Dengan demikian item pengukuran pada masing-masing indikator dalam variabel-variabel penelitian dinyatakan reliabel dan selanjutnya dapat digunakan dalam penelitan.

C. Hasil Uji Analisis Jalur atau Path Analysis

1. Uji Oulier

Uji Outlier Data Secara Universal Tahap I

\begin{tabular}{|l|l|l|}
\hline \hline \multirow{2}{*}{ Variabel } & \multicolumn{2}{|l|}{ Z score } \\
\cline { 2 - 3 } & Minimum & Maksimum \\
\hline $\begin{array}{l}\text { Zscore: } \\
\text { Kualitas } \\
\text { pelayanan }\end{array}$ & $-2,82902$ & 1,86802 \\
\hline $\begin{array}{l}\text { Zscore: } \\
\text { Kepercayaa } \\
\mathrm{n}\end{array}$ & $-2,91675$ & 2,20308 \\
\hline $\begin{array}{l}\text { Zscore: Niat } \\
\text { menggunak } \\
\text { an produk } \\
\text { lain }\end{array}$ & $-2,21935$ & 1,75560 \\
\hline \hline
\end{tabular}

Sumber: hasil olah data

Tabel menunjukkan tidak ada yang melebihi nilai standar yaitu \pm 3 jadi tidak perlu ada yang dibuang atau dieleminasi.

Uji Outlier Data Secara Multivariate

\begin{tabular}{|l|l|l|}
\hline \hline Kategori & $\begin{array}{l}\text { Observation } \\
\text { Data ke - }\end{array}$ & $\begin{array}{l}\text { Mahalanobis } \\
\text { d-squared }\end{array}$ \\
\hline Maksimum & 26 & 13,381 \\
\hline \multicolumn{2}{c}{ Sumber: hasil olah data } \\
\hline
\end{tabular}

Tabel menunjukkan bahwa pada pengujian outlier multivariate, nilai tertinggi dari Mahalanobis $D$ Square adalah 13,381 ada pada data ke 26 . Nilai 13,381 tersebut berada di bawah standar 16,42, sehingga data memenuhi asumsi multivariate outlier.

\section{Uji Normalitas}

Uji Normalitas Data Secara Univariate 


\begin{tabular}{|l|l|l|l|l|}
\hline \hline & Nilai & CR & Nilai & CR \\
\hline $\begin{array}{l}\text { Kualitas } \\
\text { pelayanan }\end{array}$ & $-0,288$ & $-0,644$ & 0,839 & 0,938 \\
\hline $\begin{array}{l}\text { Kepercay } \\
\text { aan }\end{array}$ & $-0,119$ & $-0,266$ & 1,913 & 2,139 \\
\hline $\begin{array}{l}\text { Niat } \\
\text { menggun } \\
\text { akan } \\
\text { produk } \\
\text { lain }\end{array}$ & $-0,067$ & $-0,149$ & 0,309 & 0,346 \\
\hline \hline
\end{tabular}

Sumber: hasil olah data

Tabel di halaman sebelumnya menunjukkan bahwa pengujian normalitas secara univariate membuktikan ketiga variabel mempunyai nilai skewness $C R$ kisaran $\pm 2,58$, sedangkan pada kurtosis tidak ada variabel yang mempunyai nilai CR melebihi 2,58. Dari hasil ini maka pengujian normalitas telah memenuhi syarat univariate normal khususnya dalam hal kurtosis.

\section{Uji Normalitas Data Secara Multivariate}

\begin{tabular}{|l|l|}
\hline \hline Nilai Multivariate & CR \\
\hline 3,459 & 2,229 \\
\hline \hline
\end{tabular}

Sumber: hasil olah data

Nilai Koefisien Jalur Pengaruh Antar Variabel

\begin{tabular}{|l|l|l|l|}
\hline \hline \multicolumn{2}{|l|}{} & $\begin{array}{l}\text { Nilai } \\
\text { Standar } \\
\text { Variabel } \\
\text { dized } \\
\text { coefisie } \\
\text { nt }\end{array}$ \\
\hline Kepercayaan & \begin{tabular}{l}
\multicolumn{2}{|l|}{$<-$} \\
-
\end{tabular} & $\begin{array}{l}\text { Kualitas } \\
\text { Pelayan } \\
\text { an }\end{array}$ & 0.129 \\
\hline $\begin{array}{l}\text { Niat ulang } \\
\text { dengan } \\
\text { menggunakan } \\
\text { produk yang lain }\end{array}$ & $\begin{array}{l}<- \\
\text { Kualitas } \\
\text { Pelayan } \\
\text { an }\end{array}$ & 0.220 \\
\hline \hline
\end{tabular}

\begin{tabular}{|l|l|l|l|}
\hline \hline $\begin{array}{l}\text { Niat ulang } \\
\text { dengan }\end{array}$ & $<-$ & Keperca & 0.244 \\
$\begin{array}{l}\text { menggunakan } \\
\text { produk yang lain }\end{array}$ & -- & yaan & \\
\hline \hline
\end{tabular}

Sumber: hasil olah data

Dari tabel tersebut diatas, maka diketahui bahwa :

1. Jika variabel kualitas pelayanan berubah maka akan menyebabkan perubahan kepercayaan. Tanda positif menunjukkan perubahan yang searah yaitu jika variabel kualitas pelayanan meningkat maka kepercayaan akan meningkat, dan sebaliknya apabila variabel kualitas pelayanan menurun maka kepercayaan juga akan menurun dengan nilai koefisien jalur 0.129.

2. Jika variabel kualitas pelayanan berubah maka akan menyebabkan perubahan niat ulang dengan menggunakan produk yang lain. Tanda positif menunjukkan perubahan yang searah yaitu jika variabel kualitas pelayanan meningkat maka niat menggunakan produk lain akan meningkat, dan sebaliknya apabila variabel kualitas pelayanan menurun maka niat menggunakan produk lain akan meningkat juga akan menurun dengan nilai koefisien jalur 0.220.

3. Jika variabel kepercayaan berubah maka akan menyebabkan perubahan niat ulang dengan menggunakan produk yang lain. Tanda positif menunjukkan perubahan yang searah yaitu jika variabel kepercayaan meningkat maka niat ulang dengan menggunakan produk yang lain akan meningkat, dan sebaliknya apabila 
variabel kepercayaan menurun maka niat ulang dengan menggunakan produk yang lain juga akan menurun dengan nilai koefisien jalur 0.244.

Berdasarkan nilai koefisien analisis jalur dapat diketahui bahwa nilai koefisien jalur lebih besar pada jalur kualitas pelayanan melalui kepercayaan terhadap niat menggunakan produk lain dibandingkan nilai koefisien jalur kualitas pelayanan terhadap niat ulang dengan menggunakan produk yang lain.

Pengujian path analysis menurut Hair, Anderson (1998) haruslah memenuhi persyaratan multivariate normal. Dikatakan memenuhi asumsi multivariate normal jika nilai CR multivariate kurang dari 2,58. Sedangkan pada pengujian multivariate telah memenuhi syarat karena diperoleh nilai 2.229 yang lebih rendah dari $\pm 2,58$. Dari hasil pengujian ini maka data penelitian memenuhi syarat uji normalitas.

3. Hasil Pengujian Analisis Jalur atau Path

\section{Analysis}

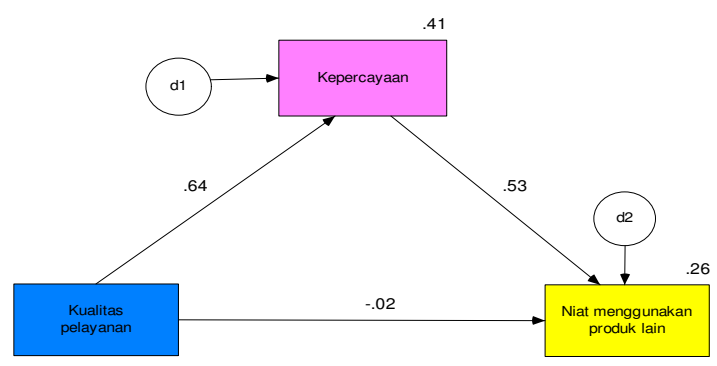

Hasil Pengujian Path Analysis

\section{Koefisien Determinasi}

Nilai Koefisien Determinasi

\begin{tabular}{|c|c|}
\hline Variabel & $\mathbf{R}^{2}$ \\
\hline $\begin{array}{l}\text { Kualitas pelayanan } \rightarrow \\
\text { Kepercayaan }\end{array}$ & $41 \%$ \\
\hline
\end{tabular}

\begin{tabular}{|lrr|l|}
\hline \hline \multicolumn{2}{|l|}{ Kualitas pelayanan } & dan & \\
kepercayaan & $\rightarrow$ & niat & \\
Ulang & dengan & $26 \%$ \\
menggunakan & produk & \\
yang lain & & \\
\hline \hline
\end{tabular}

Sumber: hasil olah data

Berikut adalah penjelasan tabel di atas:

1. Besarnya perubahan kepercayaan yang disebabkan oleh adanya kualitas pelayanan $(X)$ adalah $41 \%$. Dengan kata lain pengaruh kualitas pelayanan terhadap kepercayaan adalah $41 \%$.

2. Besarnya perubahan niat ulang dengan menggunakan produk yang lain yang disebabkan oleh adanya kualitas pelayanan (X) dan kepercayaan (Z) adalah 26\%. Dengan kata lain pengaruh kualitas pelayanan dan kepercayaan terhadap niat ulang dengan menggunakan produk yang lain adalah $26 \%$.

\section{Pembuktian Hipotesis}

Hasil Pengujian Hipotesis Pengaruh Langsung

\begin{tabular}{|l|l|l|l|l|}
\hline \hline \multicolumn{2}{|l|}{ Variabel } & $\begin{array}{l}\text { CR } \\
\text { hitung }\end{array}$ & $\begin{array}{l}\text { Tingka } \\
\text { t Sig. }\end{array}$ \\
\hline $\begin{array}{l}\text { Keperca } \\
\text { yaan }\end{array}$ & $<---$ & $\begin{array}{l}\text { Kualitas } \\
\text { pelayana } \\
\mathrm{n}\end{array}$ & 4,518 & $* * *$ \\
\hline $\begin{array}{l}\text { Niat } \\
\text { dengan } \\
\text { menggu } \\
\text { nakan } \\
\text { produk } \\
\text { yang } \\
\text { lain }\end{array}$ & $<---\begin{array}{l}\text { Kualitas } \\
\text { pelayana } \\
\mathrm{n}\end{array}$ & $-0,119$ & 0,905 \\
\hline $\begin{array}{l}\text { Niat } \\
\text { dengan } \\
\text { menggu } \\
\text { nakan } \\
\text { produk } \\
\text { yang } \\
\text { lain }\end{array}$ & $<---\begin{array}{l}\text { Kepercay } \\
\text { aan }\end{array}$ & 2,539 & 0,011 \\
\hline \hline
\end{tabular}

Sumber: hasil olah data 
Pengujian Hipotesis pertama : kualitas pelayanan mempunyai pengaruh positif terhadap kepercayaan

Pengujian dengan menggunakan nilai CR diperoleh nilai 4,518 dengan tingkat signifikansi ${ }^{* * *}$. Tanda ${ }^{* * *}$ berarti nilai signifikansinya 0,000 . Nilai signifikansi ini kurang dari 0,05 . Sehingga hipotesis pertama yang menyatakan kualitas pelayanan mempunyai pengaruh positif terhadap kepercayaan diterima kebenarannya.

Pengujian Hipotesis kedua : kualitas pelayanan mempunyai pengaruh negatif terhadap niat ulang dengan menggunakan produk yang lain

Pengujian dengan menggunakan nilai CR diperoleh nilai -0.119 dengan tingkat signifikansi 0.905. Nilai signifikansi ini lebih dari 0,05. Sehingga hipotesis kedua yang menyatakan kualitas pelayanan mempunyai pengaruh positif terhadap niat ulang dengan menggunakan produk yang lain tidak diterima kebenarannya.

\section{Pengujian Hipotesis ketiga : kepercayaan} mempunyai pengaruh positif terhadap niat ulang dengan menggunakan produk yang lain

Pengujian dengan menggunakan nilai CR diperoleh nilai 2.539 dengan tingkat signifikansi 0.011 . Nilai signifikansi ini kurang dari 0,05 sehingga hipotesis ketiga yang menyatakan kepercayaan mempunyai pengaruh positif terhadap niat ulang dengan menggunakan produk yang lain diterima kebenarannya.
Koefisien Jalur Tidak Langsung

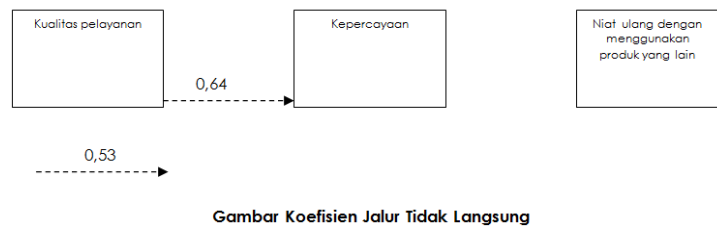

Gambar di halaman sebelumnya menunjukkan bahwa koefisien jalur tidak langsung dari kualitas pelayanan terhadap niat menggunakan produk lain melalui kepercayaan merupakan perkalian dari koefisien jalur langsung dari kualitas pelayanan terhadap kepercayaan yaitu 0,64 dan kepercayaan terhadap niat ulang dengan menggunakan produk yang lain dengan nilai 0,53 . Sehingga nilai koefisien tidak langsung adalah $0,64 \times 0,53=0,3392$

Hasil penelitian ini menunjukkan bahwa pengaruh koefisien jalur tidak langsung lebih besar dibandingkan dengan pengaruh langsung. Dengan hasil ini, peran variabel kepercayaan relatif penting sebagai mediasi kualitas pelayanan terhadap niat ulang dengan menggunakan produk yang lain.

\section{Pembahasan}

\section{Pengaruh Kualitas Pelayanan terhadap Kepercayaan}

Menurut hasil penelitian yang telah dilakukan, hasil penelitian menunjukkan kualitas pelayanan mempunyai pengaruh positif terhadap kepercayaan Pengujian dengan menggunakan nilai $\mathrm{CR}$ diperoleh nilai 4,518 dengan tingkat signifikansi ${ }^{* * *}$. Tanda ${ }^{* * *}$ berarti nilai signifikansinya 0,000 . Nilai signifikansi ini kurang dari 0,05. Sehingga hipotesis pertama yang menyatakan kualitas pelayanan 
mempunyai pengaruh positif terhadap kepercayaan diterima kebenarannya. Jadi dalam penelitian ini dapat diketahui bahwa kualitas pelayanan yang diberikan oleh Bank Syariah Mandiri Boulevard Cabang Surabaya seperti pelayanan dengan sistem bagi hasil, penyedian tabungan, dan jaminan keamanan nasabah dalam bertransaksi dapat meningkatkan kepercayaan nasabah. Sistem bagi hasil dan keamanan dalam bertransaksi perlu dipertahankan karena merupakan faktor yang paling mempengaruhi kepercayaan nasabah. Hal ini sesuai dengan hasil kuesioner yang ditunjukkan pada tabel 4.6 bahwa yang mendapatkan nilai tertinggi adalah pemberian bagi hasil $\left(X_{1.3}\right)$ dengan nilai rata-rata 3,27 dan jaminan keamanan nasabah dalam bertransaksi $\left(X_{1.11}\right)$ dengan rata-rata 3,27. Adapun kedua indikator tersebut bisa mendapatkan nilai tertinggi karena kedua indikator tersebut merupakan pelayanan yang paling dirasakan paling baik oleh nasabah.

\section{Pengaruh Kualitas Pelayanan Terhadap Niat Ulang Dengan Menggunakan Produk Yang Lain}

Menurut hasil penelitian yang telah dilakukan, hasil penelitian menunjukkan kualitas pelayanan tidak mempunyai pengaruh positif terhadap niat ulang dengan menggunakan produk yang lain. Pengujian dengan menggunakan nilai $C R$ diperoleh nilai $-0,119$ dengan tingkat signifikansi 0,905 . Nilai signifikansi ini lebih dari 0,05 . Sehingga hipotesis kedua yang menyatakan kualitas pelayanan mempunyai pengaruh positif terhadap niat menggunakan produk lain ditolak. Hal ini tidak sesuai dengan teori Crownin dan Taylor (1992) yang menyatakan bahwa kualitas pelayanan mempunyai peranan penting dalam mempengaruhi niat nasabah.

Berdasarkan penelitian ini, ternyata kualitas pelayanan yang diberikan oleh Bank Syariah Mandiri Cabang Boulevard Surabaya tidak mampu membuat nasabah untuk menggunakan ulang produk bank tersebut. Kepercayaan antara nasabah dengan bank akan terjalin baik jika bank mampu memberikan pelayanan yang jujur dan mampu memberikan kesan baik agar niat ulang nasabah dalam menggunakan produk bank meningkat. Kepercayaan juga bisa tumbuh dari sifat amanah yang dapat ditampilkan dalam keterbukaan, kejujuran, dan pelayanan yang optimal kepada nasabah.

Hubungan Kepercayaan Terhadap Niat Ulang Dengan Menggunakan Produk Yang Lain

Menurut hasil penelitian, kepercayaan mempunyai pengaruh positif terhadap niat menggunakan produk lain. Pengujian dengan menggunakan nilai CR diperoleh nilai 2.539 dengan tingkat signifikansi 0.011 . Nilai signifikansi ini kurang dari 0,05 sehingga hipotesis ketiga yang menyatakan kepercayaan mempunyai pengaruh positif terhadap niat ulang 
dengan menggunakan produk yang lain diterima kebenarannya. Dengan adanya kepercayaan yang terjalin baik antara bank dengan nasabah, akan mempengaruhi niat nasabah dalam menggunakan ulang produk bank tersebut atau bahkan mencoba menggunakan produk yang lain.

Hubungan kepercayaan terhadap niat beli ulang diperkuat dengan teori dimana kepercayaan sering dianggap sangat penting untuk hubungan jangka panjang dan mempengaruhi niat pada nasabah. Hal tersebut didukung oleh temuan empiris dari Eriksson Vaghult (2000) dan Sirdesmukh et al. (2002) yang menjelaskan bahwa kepercayaan secara langsung mempengaruhi niat beli ulang. Berdasarkan hasil kuesioner, pemberian pelayanan produk secara Istiqomah $\left(Z_{1.1}\right)$, pemberian produk yang memberikan manfaat $\left(Z_{1.2}\right)$, adanya kredibilitas tinggi dalam pemberian pelayanan $\left(Z_{1.3}\right)$, pelayanan nasabah secara efisien $\left(Z_{1.4}\right)$, pemberian respon yang baik $\left(Z_{1.5}\right)$, dan pemberian kesan yang baik terhadap nasabah $\left(Z_{1.6}\right)$ mampu mempengaruhi niat ulang nasabah Bank Syariah Mandiri Boulevard Surabaya dengan menggunakan produk yang lain.

\section{SIMPULAN}

Simpulan yang dapat diambil dari hasil penelitian yang sudah dilakukan dengan menggunakan uji statistik adalah sebagai berikut :
1. Kualitas pelayanan berpengaruh signifikan terhadap kepercayaan nasabah Bank Syariah Mandiri Kantor Cabang Boulevard di Surabaya.

2. Kualitas pelayanan tidak berpengaruh signifikan terhadap niat ulang dengan menggunakan produk Bank Syariah Mandiri yang lain. Kualitas pelayanan tidak berpengaruh langsung terhadap niat ulang dengan menggunakan produk Bank Syariah Mandiri yang lain tetapi kualitas pelayanan bisa berpengaruh terhadap niat ulang dengan menggunakan produk yang lain melalui kepercayaan sebagai variabel intervening.

3. Kepercayaan berpengaruh signifikan terhadap niat ulang nasabah Bank Syariah mandiri Kantor Cabang Boulevard di Surabaya dengan menggunakan produk yang lain.

\section{DAFTAR PUSTAKA}

Ajzen, I. 1991. The Theory of Planned Behavior. Organizational Behavior and Human Decision Processes. Nomor 50. HIm. 179-211. Diunduh dari

http://people.umass.edu/psyc661/ pdf/tpb.obhdp.pdf pada November 2011.

Anshori, Muslich dan Sri Iswati. 2009. Metodologi Penelitian Kuantitatif. Surabaya: Airlangga University Press.

Arvan Pradiansyah, (1999), "Peranan Kepemimpinan dalam Membangun Kepercayaan di 
Tempat Kerja ", Usahawan, No. 19 th. XXVIII September, hal. $23-25$.

Azwar, Saiffudin. 1997. Sikap Manusia Teori dan Pengukurannya. Yogyakarta: Pustaka Belajar.

Chamhuri, N dan PJ. Batt. 2009. Factor Influencing Consumer's Choice of Retail Stores for Fresh Meat in Malaysia. (Online) diakses pada 1 Mei 2012.

Cronin, J. Joseph JR dan Steven A. Taylor. 1992. "Measuring Service Quality: A Reexamination and Extention. Journal of Marketing. Vol. 56. July, p. 55-68.

Dunn, Elizabeth. W., Huntsinger, Jeffrey., Lun, Janetta., \& Sinclair, Stacey.. 2008. The gift of similarity: Howgood and Bad Gifts Influence Relationships. Social Cognition. Volume 26: 469-481.

Eriksson, Kent and Lofmarck Vaghult. 2000. Effects on New Customer Acquisition by Retained Customers in Professional Services, 16th IMP Conference, Bath.

Ferdinand, Augusty T.2002. Kualitas Strategi Pemasaran: Sebuah Studi Pendahuluan. Jurnal Sains Pemasaran Indonesia. Vol 1, No.1. hlm. 107-119.

$\begin{array}{lll}\text { Modelling } & \text { Structural } & \text { Equation } \\ \text { Manajemen. } & \text { Edisi } & \text { Penelitian } \\ \text { pertama. }\end{array}$
Semarang: Universitas Diponegoro.
Ghozali,I. 2006. Aplikasi Analisis Multivariate dengan Program SPSS. Semarang: Badan Penerbit- UNDIP.

Hermansyah. 2008. Hukum Perbankan Nasional Indonesia. Jakarta: Prenada Media Group.

Hellier, Philip K, Gus M.Geursen, Rodney A.Carr, John A.Rickard. 2003. Costumer repurchase intention: A general structural equation model. European Journal of Marketing. Vol. 37. Issue 11.

Indriantoro, Nur dan Bambang Supomo. 2002. Metodologi Penelitian Bisnis untuk Akuntansi dan Manejemen. Edisi Pertama. Yogyakarta:BPFE.

Infobank. 2007. Vol XXIX no. 344.

Karim, Adiwarman A. 2004. Bank Islam. Jakarta: PT Rajagrafindo Persada.

Kotler, Philip dan Gary Amstrong. 2001. Prinsip-prinsip pemasaran. Edisi Kedelapan. Jakarta: Penerbit Erlangga.

dan Kevin L.Keller. 2003. Manajemen Pemasaran. Edisi Kedua. Jakarta: Indeks.

Ling, Leong Quee, M.Shahrim AK.H, Mohhidin Othman, Noranizan M Adzahan, Sridar Ramachandran. 2010. Relationship Between Malaysian Food Image, Tourist Satisfaction, and Behavioural Intention. World Applied Sciences Journal 10 (Special Issue of Tourism and Hospitality) 164-177. 
Lupiyoadi, Rambat dan A. Hamdani. 2008. Manajemen Pemasaran Jasa. Jakarta: Salemba Empat.

Maholtra, Naresh K., 1999. Marketing Research : An Applied Orientation, 3rd edition, Prentice Hall, Inc., New Jesrey.

Maholtra, Naresh K., and Avinandan Mukherjee, 2003. Analysing the Commitment Service Quality Relationship: A Comparative Study of Retail Banking Call Centres and Branches, Journal of Marketing Management, 2003, 19, 941-971.

Moorman, Christin, Gerald Zaltman and Rohit Deshpande (1993) Factors Affecting Trust in Market Research Relationship, Journal Marketing Research, Vol. 57 (January), 81-101. Morgan, Robert M., dan Shelby D. Hunt. 1994. The Commitment Trust Theory of Relationship Marketing. Journal of Marketing. Volume 58: 20-38.

Nazir, Mohammad. 2003. Metode Penelitian. Jakarta: Ghalia Indonesia.

Othman, Abdulqawi and Owen Lynn. 2001. The Multi Dimensionality of CARTER Model to Measure Customer Service Quality in Islamic Banking Industry: A Study in Kuwait Finance House. International Journal of Islamic Services. Volume 3: $1-12$.

Sari, Dhanty V.P. 2012. Pengaruh Perilaku islami Pemasar terhadap Kepercayaan dan Istiqomah yang dimoderasi oleh Tingkat pengetahuan Agama nasabah pada BRI Syariah di Surabaya.Skripsi Diterbitkan. Surabaya: Fakultas Ekonomi dan Bisnis Universitas Airlangga.

Sarwono, Jonathan. 2006. Analisis Data Penelitian Menggunakan SPSS. Jakarta: C.V. Andi Offset.

Schiffman, Leon G. And Leslie Lazar Kanuk. 2000. Consumer Behaviour. Seventh Edition. Upper SaddleRiver. New Jersey: PrenticeHall Inc.

Simamora, Bilson. 2003. Memenangkan Pasar Dengan Pemasaran Efektif Dan Profitabel. Jakarta : PT. Gramedia Pustaka Utama.

Sirdeshmukh, Deepak, Jagdip Singh, and Barry Sabol. 2002. Consumer Trust, Value, and Loyalty in Relational Exchanges, Journal of Marketing. Volume 66: 15-37.

Tasmara, Toto. 2001. Kecerdasan Ruhaniah. Jakarta: Gemalnsani Press.

Wibisono, Darmawan. 2000. Riset Bisnis. Bandung: Ganesha Exact.

Zeithaml, Valarie.A. and Bitner, Mary. Jo. 2000. Services Marketing: Integrating Customer Focus Across the Firm: 2nd Edition. London: Irwin McGraw Hill. 